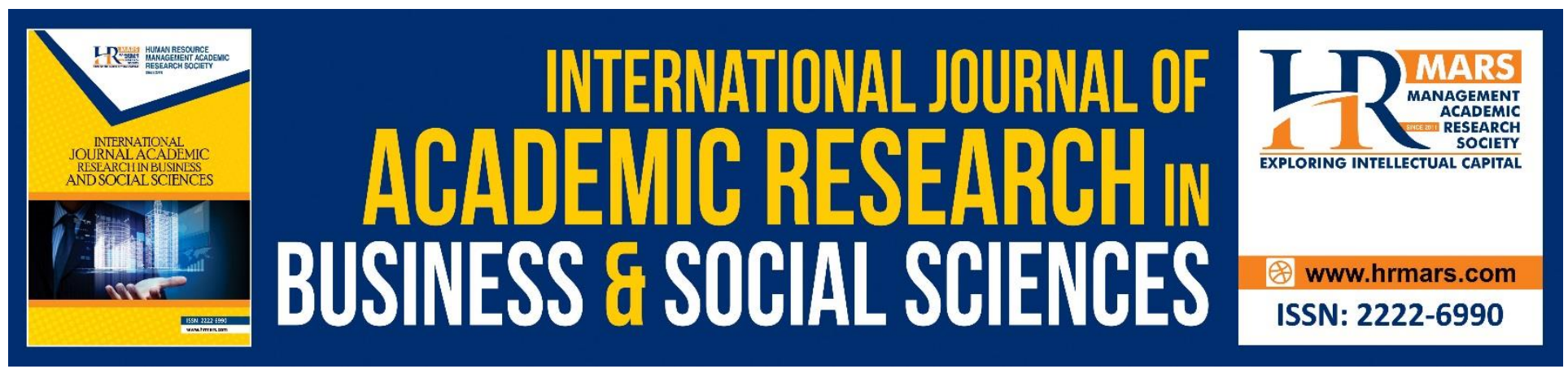

\title{
History of the Establishment and Development of Islamic Banking in Malaysia
}

Fathullah Asni

To Link this Article: http://dx.doi.org/10.6007/IJARBSS/v9-i6/5949

DOI: 10.6007/IJARBSS/v9-i6/5949

Received: 18 April 2019, Revised: 16 May 2019, Accepted: 04 June 2019

Published Online: 28 June 2019

In-Text Citation: (Asni, 2019)

To Cite this Article: Asni, F. (2019). History of the Establishment and Development of Islamic Banking in Malaysia. International Journal of Academic Research in Business and Social Sciences, 9(6), 305-315.

\section{Copyright: (C) 2019 The Author(s)}

Published by Human Resource Management Academic Research Society (www.hrmars.com)

This article is published under the Creative Commons Attribution (CC BY 4.0) license. Anyone may reproduce, distribute, translate and create derivative works of this article (for both commercial and non-commercial purposes), subject to full attribution to the original publication and authors. The full terms of this license may be seen

at: http://creativecommons.org/licences/by/4.0/legalcode

Vol. 9, No. 6, 2019, Pg. 305 - 315

Full Terms \& Conditions of access and use can be found at http://hrmars.com/index.php/pages/detail/publication-ethics 


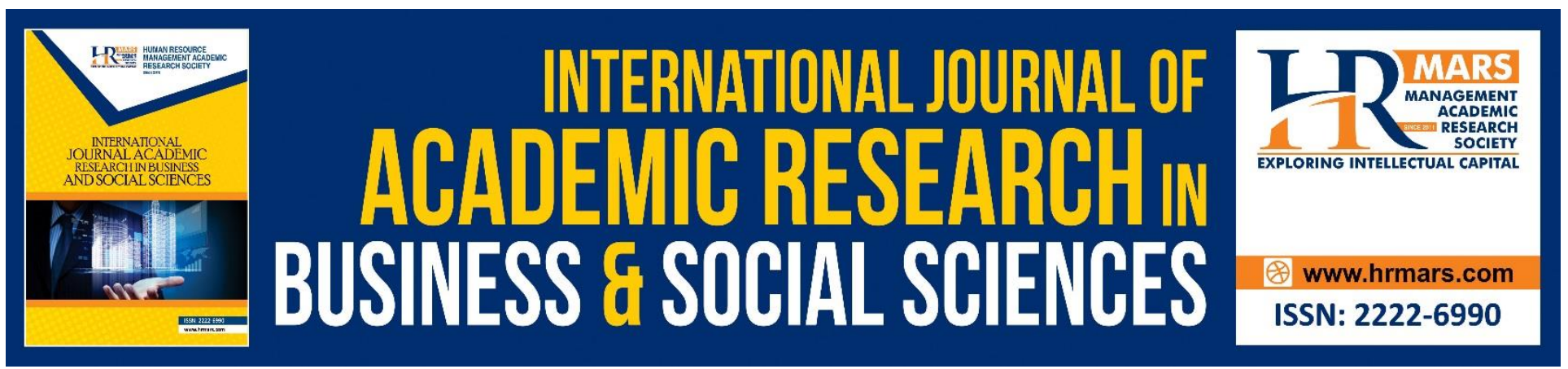

\title{
History of the Establishment and Development of Islamic Banking in Malaysia
}

\author{
Fathullah Asni \\ School of Humanities, Universiti Sains Malaysia \\ Email: fathasni90@gmail.com
}

\begin{abstract}
Free-riba Islamic muamalat transactions have been practiced in Malaysia since the 7th century in line with the advent of Islam. Officially, it was enforced in the law of Malacca in the 16th century. Among the Islamic muamalat transactions that were practiced is bay' al-wafa' or known as conditional sale. After Malaysia was colonized, the conventional banking system was established until it became the mainstream system. The success of Islamic banking in other Islamic countries and the Lembaga Urusan Tabung Haji (LUTH) has led the Muslim community to demand Islamic banking in Malaysia. However, the establishment of Islamic banking in Malaysia was not as comfortable as it was necessary to compete with long-established conventional banks. Hence, this paper is to study the history and establishment of Islamic banking in Malaysia. This study uses a qualitative method where the data are derived from literature studies, i.e. referring to secondary sources such as books and journals. The data collected were analyzed using document and content analysis methods based on the objective. The study found that the success of the establishment of LUTH and Islamic banks in the Middle East has resulted in the Malaysian community demanding to set up Islamic banking in Malaysia and the government welcomed it. The findings also found that the success of Islamic banking in Malaysia was the result of the government's initiative in introducing Islamic banking schemes (IBS) or known as (SKIM PERBANKAN ISLAM SPI) to becoming the mainstream schemes in Malaysia despite having to compete with long-established conventional banks. The study found that the development of Islamic banking was drastically due to the inherent privilege of the Islamic banking scheme, where there was an element of profit sharing and loss in every banking transaction between the bank and the customer, which was different from conventional banking scheme.
\end{abstract}

Keywords: History, Islamic Banking Scheme (IBS), Conventional banks, Islamic banks, Malaysia

\section{Introduction}

Malaysia is now known as the Islamic banking hub in which Malaysia is among the significant contributors to the growth of Islamic banking scheme around the world (Alwi et al., 2019). In Malaysia, there are 16 banks, whether banks based on the Islamic banking system or the mix based between conventional and Islamic banking schemes also offer Islamic banking schemes. This is due 
INTERNATIONAL JOURNAL OF ACADEMIC RESEARCH IN BUSINESS AND SOCIAL SCIENCES Vol. 9, No. 6, June, 2019, E-ISSN: 2222-6990 @ 2019 HRMARS

to the high demand of the local community. Similarly, the opening of Islamic-based banking is growing as there are now four banks that fully offer Islamic banking scheme namely Bank Islam Malaysia Berhad, Bank Muamalat Malaysia Berhad, Bank Rakyat and MBSB Bank Berhad (BNM 2019). However, the success of the Islamic banking scheme in Malaysia has not happened suddenly, but it has grown due to various factors. Therefore, this study will examine the history and development of Islamic banking since before and after independence.

\section{History of Islamic Muamalat Transactions before Independence}

History proved that free-riba transactions have been practiced in Malaysia as early as the 16th century. This principle can be seen in the law of Malacca. Furthermore, most of the states in Malaysia during the era before independence were also influenced by Malacca's law including those involving the aspect of free-riba transactions either directly or indirectly (Cartesa, 1944; Fang, 1976; Winstedt, 1969; Shellebear 1977). In the Malacca Act, muamalat affairs are touched from clause 29 to clause 34.2 as in the clause stating the prohibition of riba in a sale or exchange transaction, i.e. in clause 30 affecting the law on the sale and prohibition of usury transactions (Nasohah, 2004).

However, it is believed that the free-riba transaction has been practiced earlier than the 16th century because history records that Islam had come to Malaysia, which began in Kelantan since the 7th century, then spread to Kedah, Pahang, Terengganu, Melaka, Johor, Perak and into the subsequent states of the same century. This is undoubtedly the activities of free-riba transactions have been carried out although it was not enforced in law because the transaction of riba is a matter which Islam is highly demanded to avoid (Abdullah, 1989).

There is also evidence of the use of the principle of free-riba transaction that is conditional sale practiced by the Malay community, especially by farmers in Kedah, Perlis, North Perak and Kelantan before pre-colonial era. This transaction was practiced as they dismissed the lending-based loans managed by the Ceti at that time (Maxwell, 1884; Hooker, 1970; Gullick, 1987). Buang (1993) described the conditional sale as the principle of Islamic transactions known as al-bay' al-wafa', i.e. selling goods with the option to buy back. Al-Bay' al-Wafa' contains two words, i.e. al-bay' and alwafa', from a language perspective, al-bay' means sale and al-wafa' means repayment or settlement of a debt. The scholars defined the al-bay' al-wafa' as a sale by two parties that there is a condition that the seller can repurchase the goods at the expiry of a certain period which has been mutually agreed (al-Zarqa, 1968). This form of transaction is aimed at raising capital free of usury in the cultivation of paddy and many more and avoiding obtaining funding from the Ceti or financial institution that practicing a riba transaction (Hassan, 2005).

This contract was initially practiced by residents in Central Asia (Bukhara and Balkh) in the middle of the 5th century of Hijrah to avoid obtaining loans with the element of riba. Subsequently, the practice continued to expand into the Middle East, then brought to the archipelago by preachers in line with the inclusion of Islam (Al-Sabuni, 1980). The contract that becomes the culture of this local community was practiced to obtain credit facilities without being involved with the element of riba. Usually, this transaction is practiced in the sale of land or property of the seller to the buyer with an undertaking to repurchase within a specified period. During that period, the buyer can use and occupy the land. If within the promised period, the seller fails to repurchase his property, it will transfer to the buyer (Salleh, 1988). However, the majority of the scholars denied the validity of bay' 
al-wafa' by judging it as a damaged sale because there is a hilah (trick) element to replace usury transaction and included the condition in the sale (Hawwa, 2007). It was also confirmed by Majma' Fiqh al-Islami (1992) decision in 1992.

The activity of conditional sale transaction has earned attention in cases decided by the previous Judge. Among them is in Tungku Zahara v Che Yusof (1951 MLJ 1) case, Judge Briggs decided that the purpose of the conditional sale transaction was to obtain credit and to give creditors (land buyers) the corresponding compensation indemnity without engaging with the practice of usury that any Muslim is prohibited from engaging with it. In the case of Mohamed Isa v. Ibrahim Ibrahim (1968) $1 \mathrm{ML}$ 186, Judge Azmi as the Chief Judge of Malaya had made the same statement and the customary practice of the Kedah farmers was essentially a conditional sale transaction where the seller had the right to repurchase his property and to enable the buyer (borrower of money) to benefit from legal transactions according to Islamic law $(, 1996)$. These statements reinforce and prove that the bay' alwafa' transaction was an alternative by the Malay community at that time to avoid the riba transaction.

\section{History of Islamic Banking in Malaysia after Independence}

However, the contract which became the practice and culture of the local community was crucial to be developed and become the basis of offering Islamic banking products, especially capital financing products. The target group of the product was small farmers who cultivate paddy, coconut, palm oil, vegetables and many more when they were difficult to obtain capital from other sources. At this time, the land was essential for the needs of the local community as the majority were farmers (Shamsuddin 1988). In addition to the land for agricultural activities and income sources, the land was also the place to live. Indirectly the principle of asset financing in Malaysia at that time was based on the conditional sale contract.

However, the free-riba transaction was carried out individually. At the institutional level, the Lembaga Urusan Tabung Haji (LUTH) now known as Lembaga Tabung Haji (LTH) was established in 1969 (Borhan \& Sa'ari, 2005). It is a savings institution in the Malaysian financial system. Some researchers consider LUTH as the world's first Islamic financial institution and is an example of the best model (Ghani, 1997). The establishment aims to enable Muslims to save money gradually to fulfill the expenditure of the pilgrimage and engage in the field of capital financing in corporate, commercial, plantation and real estate that are Syariah compliant.

Reflecting on the success of the establishment of Islamic banks in several Islamic countries such as Qatar, UAE, Egypt, Pakistan and Iran, Muslims in Malaysia had also expressed the desire for Islamic banks to be established in Malaysia. In 1980, the Bumiputera Economic Congress approved a proposal to request the government to allow the Lembaga Urusan dan Tabung Haji (LUTH) to set up an Islamic bank to collect and invest Muslims money in the field of halal and profitable investment. In March 1981, a seminar titled "Concept of Development in Islam" held at Universiti Kebangsaan Malaysia (UKM) had approved a resolution asking the government to take immediate action to enact legislation to enable the establishment of banks and financial institutions operating on Islamic principles (Hassan, 2005).

The desire to establish Islamic banks has also been voiced at the state level as well as by the Muslim community. The efforts to establish Islamic banks were implemented separately in 1980 by 
LUTH, the Malaysian Islamic Welfare Organization (PERKIM) and individuals (Zaim et al., 2015). As a result of this effort, the government has received recommendations from the Lembaga Tabung Haji so that the steps to establish Islamic banks were coordinated at the national level. Subsequently, on July 30, 1981, the government appointed the National Steering Committee chaired by YM Raja Tan Sri Mohar Raja Badiozaman and LTH appointed as the secretary. To prepare a report, the Committee has referred to the operations of Faisal Islamic Bank in Sudan and Faisal Islamic Bank in Egypt as guidelines (Haron, 2008).

The report of the committee was submitted to the Government on 5 July 1982, which has suggested some of the following (Guan 2002):

a) An Islamic bank operating following Islamic law shall be established,

b) The Islamic Bank shall be incorporated as a company under the Companies Act 1965,

c) Since the 1973 Bank Act was not suitable for the operations of Islamic banks, then a legal provision known as the Islamic Banking Act 1983 should be proposed to license and monitor Islamic banks, and some amendments have to be made to the existing laws,

d) Bank Negara Malaysia, the central bank should administer the Islamic Banking Act 1983 and,

e) The Islamic Bank shall establish Syariah Supervisory Council (Adviser) to determine that it carries out its business following Islamic law.

The National Steering Committee report on Islamic banking in Malaysia outlines two fundamental principles that should be implemented in the operations and practices of Islamic banking (Haron, 1997):

1. Prohibition of usury and the implementation of profit and loss sharing systems in all economic activities. The concept of profit and loss sharing should replace the interest mechanism in Islamic banking operations and based on Islamic transactions so that its activities are not contrary to sharia principles and,

2. Keep away from all activities that are contrary to the interests of Muslims. Its activities which are not in line with the interests of Muslims are considered as abuse of wealth entrusted by Allah SWT.

Therefore, the first Islamic Bank established in Malaysia is Bank Islam Malaysia Berhad (BIMB). It was incorporated as a company under the Companies Act 1965 on 1 March 1983 which was named as BIMB in which its registered office in Malaysia. The business operation began in July 1983 with a branch in Kuala Lumpur. Its Memorandum and Governance outlines the ways and objectives of the business are as follows (BIMB 1984):

"...all business conduct carried out by the company must follow the principles, rules and practices of Islam. The main purpose of its establishment is to conduct Islamic banking in all its departments and branches. Bank Islam is prohibited from carrying on any business activities that are not in line with the requirements of Shariah."

The BIMB Moto is "Progressive, Professional and Friendly" has a mission to strive to run its operations as a commercial bank based on Sharia principles. To provide Islamic banking products and services to all societies in Malaysia by achieving thriving and competitive capabilities from time to time (Ghani 1999). 
The most important operation of BIMB based on Islamic principles is to implement the nonusury banking and finance scheme. The practice of applying usury in all banking and financial arrangements as in conventional banks and financial institutions is replaced with a profit and loss sharing system. The profit and loss sharing system to depositors, investors and bank's shareholders. The establishment of BIMB is not merely to profit in its business but also to achieve social, moral and community welfare goals according to Islam. Hence, BIMB sets its corporate objectives as follows (Borhan, 2001),

"The corporate goal of the bank is to provide banking facilities and services based on principles, rules and practices of Islam to all races and people of this country. These principles, rules and practices are based on Islamic muamalat (Ahkam al-Mu'amalat al-Islamiyyah) laws relating to banking and finance matters. The bank's efforts to provide these facilities and services will be carried out taking into account the areas of expertise and its ability to grow and progress continuously from time to time."

The other corporate goals are as follows:

a. providing customers with the highest quality of Islamic banking facilities and services,

b. achieving a strong and profitable rate of profit to keep it growing,

c. develops authoritative and innovative management with high trustworthiness, create a motivated workforce with appropriate work ethics and fully committed to the bank and provide efficient and courteous service to customers,

d. always strives to preserve the interests of shareholders and,

e. always aware of its obligations and responsibilities as citizen of Islamic institution.

BIMB was established with a capital of RM500 million. The establishment of BIMB and the creation of several Islamic financial instruments until the late 1980s was the first phase of the implementation of the Islamic Banking System (IBS) in Malaysia (Ismail 1983).

While in the 1990s, it was the second phase of the development of the Islamic Banking System which brought this system from the periphery of the banking system in Malaysia to the mainstream system (Yakcop, 1996). The IBS is a scheme designed to allow conventional financial institutions to offer Islamic banking products that implemented in stages. All commercial banks, merchant banks and finance companies were eligible to participate in IBS. The first phase of the IBS was launched in March 1993 involving the three largest commercial banks in Malaysia namely Malayan Banking Berhad (MBB), Bank Bumiputera Malaysia Berhad (BBMB) and United Malayan Banking Corporation Berhad (UMBCB) (Borhan, 2001). These three conventional bank institutions were granted permission to offer Islamic banking scheme. Among the facilities offered were deposit accounts, asset ownership financing and Syariah-based trade financing such as wadi'ah, mudarabah, bay' bithaman' ajil, ijarah, kafalah and wakalah (Ghani 1999). The IBS service has received encouraging response from the public. Through 281 branches in the three banks, within two months of operation, they had attracted 4,146 depositors and raised 30 million deposits (Guan, 2002).

The second phase of the IBS implementation launched on 21 August 1993 involved ten other financial and banking institutions in Malaysia (Borhan, 2001). Among them were Perwira Habib Bank Berhad, Arab Malaysian Finance Berhad and Maybank Finance Berhad. At that time, the entire branch 
INTERNATIONAL JOURNAL OF ACADEMIC RESEARCH IN BUSINESS AND SOCIAL SCIENCES Vol. 9, No. 6, June, 2019, E-ISSN: 2222-6990 @ 2019 HRMARS

of financial institutions offering IBS amounted to 440 units excluding $44 \mathrm{BIMB}$ branches. As at the end of December 1995, the number of financial institutions that participated in IBS was 42 with the number of branches offering IBS facilities of 1472, i.e. 1406 branches offering IBS and 66 BIMB branches (Borhan, 2001).

On 1 October 1999, Bank Muamalat Malaysia Berhad (BMMB) was established as the second Islamic bank in Malaysia. BMMB was formed by the government's efforts to strengthen the Islamic banking sector to meet the increasing demand of the public on Islamic banking services. The Bank was formed as a result of the combined Bank Bumiputera Malaysia Berhad (BBMB) and Bank of Commerce Malaysia Berhad which eventually establish Bumiputera-Commerce Bank Berhad and Bank Muamalat Malaysia Berhad (BMMB) (Borhan, 2001). BMMB, which has a total of 1000 employees at the beginning of its establishment, has operated in 40 branches nationwide including in Sabah and Sarawak, headquartered in Kuala Lumpur. It has started its operations with a shareholders' fund of RM30 million and acquisition of SPI's assets of RM3 Billion from Bank Bumiputera Malaysia Berhad, BBMB and Bank of Commerce (M) Berhad. From the point of ownership of the stock, Commerce Asset-Holding Berhad (CAHB) has allocated 30 percent of its shares in BMMB, while the rest is wholly owned by the Malaysian government (Hassan 2005).

On 5 May 1993, the Islamic Banking System was introduced at Bank Kerjasama Rakyat Malaysia (Bank Rakyat) which started in its four branches. This launched scheme refers to the Islamic banking and financial system operated by a cooperative bank without any element of riba. Among the sharia contracts used by Bank Rakyat are al-wadi'ah, al-mudarabah, al-murabahah, al-rahnu, bay' al-'enah. Since the inclusion of the Islamic banking scheme, the process of transformation from the conventional banking system to the Islamic banking system occurred step by step (Borhan, 2001). At the end of 1995, 40 Bank Rakyat branches were fully operational in Islamic banking. This effort was to ensure that the Islamic banking system based on Islamic muamalat principles is fully implemented in Bank Rakyat (Borhan 2001).

On 6 November 2017, MBSB Bank Berhad was established which is the 4th Islamic bank in Malaysia. MBSB Bank Berhad formerly known as Asian Finance Bank Berhad (AFB) has been granted a license by Bank Negara Malaysia to undertake Islamic Banking business. MBSB Bank is regulated and supervised by Bank Negara Malaysia under the Islamic Financial Services Act, 2013. MBSB Bank Berhad, a full-fledged Islamic Bank was incorporated on 28 November 2005 is a wholly owned subsidiary of Malaysia Building Society Berhad. On 6 November 2017, MBSB entered into a Share \& Purchase Agreement with the shareholders of Asian Finance Bank Berhad ("AFB/Vendors") for the proposed acquisition by MBSB of the entire equity interest in AFB for an aggregate purchase consideration of RM644,952,807.66 to be satisfied by way of cash amounting to RM396,894,036.26 and the issuance of 225,507,974 Consideration Shares at an issue price of RM1.10 per Consideration Share ("the Acquisition"). The Acquisition was approved by the shareholders' of MBSB on 23 January 2018. The shareholders also approved the transfer of Shariah Compliant Assets and Liabilities of MBSB to AFB via a Members' Scheme of Arrangement. Pursuant to the abovesaid approval and upon completion of the transfer of shares and the payment of the balance of the purchase consideration to the Vendors, AFB became a wholly owned subsidiary of Malaysia Building Society Berhad on 7 February 2018. AFB undertook a rebranding exercise and on 2 April 2018 it changed its name to MBSB Bank Berhad (MBSB 2019). 
The established Islamic banks are following the BIMB model. It is now recorded by BNM (2019) that 16 banks are offering Islamic banking scheme which comprises Islamic and conventional banks. The Islamic banking scheme is offered by most banks in Malaysia as there is a high demand for Muslims and non-Muslims in Malaysia. Besides, the privilege of Islamic banking scheme has become a factor in the development of Islamic banking in Malaysia where there is an element of profit and loss sharing in every banking transaction. This makes that whatever natural risk is not only borne by one party solely as in conventional banking scheme, but it is borne by both parties, i.e. bank and customer (Amin, 2008). This factor has led Islamic banking scheme to attract banks and communities with various religious and racial backgrounds to participate.

\section{Profit and Loss Sharing in Islamic Banking Practices}

The profit and loss sharing system is an alternative mechanism for a conventional banking system based on usury. The sharing system is a method and mechanism that is in line with the Islamic economic framework that is free from the practice of usury. In practice, the Muslim community is incapable of escaping from a riba-based transaction as long as riba-based banking and conventional institutions are still operating (Siddiqi, 1985). To overcome this problem, the scholars of Islamic economics have put forward various forms of Shariah-compliant alternatives, i.e. profits or returns to a party in an agreement are in terms of ratio $(1 / 2,1 / 3$ and $1 / 4)$ and the loss will be borne by the capital owners depending on their capital contribution (Borhan, 2001).

Theoretically, this profit and loss sharing system is based on profit sharing and partnership, which are two forms of joint venture contracts. In addition to the profit and loss sharing system, several other methods have also been used to replace the riba-based system, among others: rental (al-ijarah), hire purchase (al-ijarah thumma al-bay'), a sale with a deferred payment (bay' bithaman 'ajil BBA) and the capital price plus profit (al-murabahah) (Chapra, 1985).

The profit and loss sharing system is a mechanism that describes the relative role of entrepreneurial capital that is not considered as a separate factor and has a different base in terms of returns. On the other hand, both factors have a consistent basis in the case of returns. In Islam, capital is regarded as a stored labor factor contained in it an item and is used in the production of other goods (Malik, 1972). Return on capital is in the form of profits or rent by type of capital. While entrepreneurs are the manpower that manages, governs and possesses other production factors such as land, capital and labor in production activities. Entrepreneurs are responsible for the course of production activities, and their returns are in the form of surplus profits after all returns are distributed to other factors involved in the activity (Al-Su'ud, 1968). In other words, returns to entrepreneurs depend on their ability, diligence and experience, and they cannot be held responsible for incurring losses if not due to negligence (Siddiqi, 1981).

This approach is very different from the conventional economic system that emphasizes capital provision and gives it a constant and natural value regardless of the risks and uncertainties faced by entrepreneurs. In comparison, Islam has taken note of justice rather than protection against any particular interest (Samuelson, 1977). Riba-based banking and financial system reforms to profit and loss sharing system is not only from a technical point of view but must utilize financing mechanisms that are in line with the requirements of shariah and the Islamic community. Furthermore, financial activities are to achieve the objectives of Islamic socio-economic welfare. 
These objectives if successful will increase economic growth that will eradicate poverty, create justice and distribute income and wealth and adequate employment opportunities (Chapra, 1985).

The existence of banks and Islamic financial institutions is not measured to the extent of succeeding in eliminating usury and profit from operations and investments made but also covering the socioeconomic objectives required by the Muslim community (al-Su'ud 1968). For example, in the form of mobilizing savings, widespread entrepreneurial enhancement, savings efficiency utilizing the basic needs of Islamic societies such as homes and vehicles, reducing the concentration of wealth to a group of people. Although all these things are not achieved in a short period, at least they continue to strive to achieve them in the long run. This is because the orientation of socioeconomic welfare is a challenge for banks and Islamic financial institutions that are free from the element of riba (Kahf, 1978).

\section{Conclusion}

The free-riba Islamic muamalat transaction in Malaysia has been practiced since before independence where it began in tandem with the arrival of Islam in Malaysia in the 7th century. However, it was officially recorded that free-riba muamalat transactions were enforced in the law of Melaka in the 16th century. It continues to be practiced in other states because of its influence over the laws of Malacca. The popular Islamic financing used at the time was bay' al-wafa' or known as a conditional sale where it lasted until the establishment of Islamic banking. However, it was performed on individual capacity. It has been a driving force for developing and becoming the basis of Islamic banking product offerings. In addition, the successful establishments of the Lembaga Urusan Tabung Haji (LUTH) in 1969 and Islamic banks in the Middle East further enhanced the Islamic banking system. It has been a factor for the Muslim community in Malaysia to demand the establishment of Islamic bank in Malaysia. The claim was welcomed by the government when the Islamic Banking Act 1983 was drafted to permit the opening of Islamic banks in Malaysia. Thus, Bank Islam Malaysia Berhad was successfully established in 1983. At the beginning of its operations, BIMB has taken the model of Islamic banking operations from Faisal Islamic Bank in Sudan and Faisal Islamic Bank in Egypt as the main guide.

However, the establishment of an Islamic bank in Malaysia is not comfortable as it is necessary to compete with long-established conventional banks. But the government's initiatives and privileges in Islamic banking products have attracted other banks and local communities, whether Islamic or non-Islamic to participate in Islamic banking schemes. Now Islamic banking scheme has become the mainstream scheme where 16 banks in Malaysia have offered IBS, and there are already four banks that are fully operational based on the Islamic banking system.

\section{Corresponding Author}

Fathullah Asni

School of Humanities, Universiti Sains Malaysia, 11800 Pulau Pinang, Malaysia

Email: fathasni90@gmail.com 
INTERNATIONAL JOURNAL OF ACADEMIC RESEARCH IN BUSINESS AND SOCIAL SCIENCES

Vol. 9, No. 6, June, 2019, E-ISSN: 2222-6990 @ 2019 HRMARS

\section{References}

Abdullah, A. R. H. (1989). Islam dalam sejarah Asia Tenggara tradisional. Kuala Lumpur: Penerbitan Pena.

Al-Sabuni, A. (1980). al-Madkhal li Dirasah al-Tasyri' al-Islami. Dimasyq: Matba'ah al-Riyad.

Al-Su'ud, M. (1968). Khutut Ra'isiyyah fi al-lqtisad al-Islami. Kuwait: Maktabah al-Manar alIslamiyyah.

Alwi, S. F. S., Jaafar, M. N., Osman, I., \& Afif, A. (2019). The Development of Islamic Trade Finance in Malaysia: From the Bankers' Perspectives. In Contemporary Management and Science Issues in the Halal Industry (pp. 461-467). Springer, Singapore.

Al-Zarqa', M. (1968). Sharh al-Qanun al-Suri, al-'Uqud al-Musawamah. Dimasyq: Dar al-Kitab.

Amin, H. (2008). Choice criteria for Islamic home financing: empirical investigation among Malaysian bank customers. International Journal of Housing Markets and Analysis, 1(3), 256-274.

BIMB. (1984). Bank Islam : Penubuhan dan Operasi. Kuala Lumpur: Usaha C \& Sdn. Bhd.

BNM. (2019). Islamic Banks. See: http://www.bnm.gov.my/index.php?ch=li\&cat=islamic\&type=|B\&fund=0\&cu=0 (accessed on 23/5/2019).

Borhan, J. T. (2001). Sistem Perbankan Islam di Malaysia: Sejarah Perkembangan, Prinsip dan Amalannya. Jurnal Usuluddin, 14, 137-164.

Borhan, J. T., \& Sa'ari, C. Z. (2005). THE ROLE OF TABUNG HAJI AS A DEPOSIT MOBILIZER OF MUSLIMS IN MALAYSIA, 1969-1990. A HISTORICAL APPROACH. Journal of Al-Tamaddun, 1(1), 215-234.

Buang, S. (1988). Ke Arah Pengislaman Kanun Tanah Negara. in Fakulti Undang-undang Universiti Malaya. Makalah Undang-undang Menghormati Ahmad Ibrahim. Kuala Lumpur: Dewan Bahasa dan Pustaka.

Buang, S. (1993). Undang-undang tanah di Malaysia. Kuala Lumpur: Dewan Bahasa dan Pustaka.

Chapra, M. U. (1985). Towards a just monetary system (Vol. 8). International Institute of Islamic Thought (IIIT).

Cortesa, A (1944). The Suma Oriental of Tom Pires. London: E.G.De Eredia.

Fang, L. Y. (1976). Undang-Undang Melaka. The Hague: Martinus Nijhoff

Ghani, A. M. A. (1997). Sistem kewangan Islam dan pelaksanaannya di Malaysia (Doctoral dissertation, Jabatan Pengajian Islam, Fakulti Sastera dan Sains Sosial, Universiti Malaya).

Ghani, A. M. A., (1999). Sistem kewangan Islam dan pelaksanaannya di Malaysia. Kuala Lumpur: Jabatan kemajuan Islam Malaysia.

Guan, C. K. (2002). Sistem Kewangan Malaysia : Struktur, Perkembangan dan Perubahan (Second Edition). Kuala Lumpur: Pearson Malaysia SDN. BHD (4409-W).

Gullick, J. M. (1987). Malay society in the late nineteenth century: The beginnings of change. USA; Oxford University Press.

Haron, S. (1997). Islamic Banking System: Concept \& Applications. Kuala Lumpur: Pelanduk Publications (M).

Haron, S. (2008). Sistem Kewangan dan Perbankan Islam, Kuala Lumpur: Kuala Lumpur Business School.

Hassan, A. A. H. (2005). Teori dan aplikasi kontemporari sistem ekonomi Islam di Malaysia. Kuala Lumpur: Utusan Publications. 
INTERNATIONAL JOURNAL OF ACADEMIC RESEARCH IN BUSINESS AND SOCIAL SCIENCES

Vol. 9, No. 6, June, 2019, E-ISSN: 2222-6990 @ 2019 HRMARS

Hawwa, A. S. (2007). Suwar al-Tahayul 'ala al-Riba. Beirut: Dar Ibn Hazm.

Hooker, M. B. (1970). Readings in Malay adat laws. Ohio University Press.

Ismail, A. H. (1983). Bank Islam Malaysia Berhad: Establishment and Operation. Proceeding Paper at International Conference on Islam and Technology, UTM, Kuala Lumpur, Dec. 1983.

Kahf, M. (1978). The Islamic Economy: An Analytical Study of the Functioning of the Islamic Economic System. Indiana: Muslim Students' Association.

Majma' al-Fiqh al-Islami. (1992). Qarar bisya'n bay' al-wafa'. See: http://www.iifa-aifi.org/1855.html (Accessed on 25/5/2019)

Malik, N. (1972). al-Muslim fi 'Alam al-lqtisad. Beirut: Dar al-Shuruq.

Maxwell, W. E. (1884). THE LAW AND CUSTOMS OE THE MALAYS WITH REFERENCE TO THE TENURE OF LAND. Readings in Malay Adat Laws, 345.

MBSB. (2019). Company Profile. See: https://www.mbsbbank.com/corporate_about_profile.html (accessed on 20/5/2019)

Nasohah, Z. (2004). Pentadbiran undang-undang Islam di Malaysia: sebelum dan menjelang merdeka. Kuala Lumpur: Utusan Publications.

Samuelson, P. A. (1977). Economics. New York: McGraw-Hill Book Co.

Shamsuddin, A. K. (1988). Banking and Public Finance in Islam. Kuala Lumpur: Dewan Pustaka Fajar. Shellebear, W.G. (1977). Sejarah Melayu. Kuala Lumpur: Penerbit Fajar Bakti Sdn. Bhd..

Siddiqi, M. N. (1981). Muslim economic thinking: a survey of contemporary literature (Vol. 1). International Centre for Research in Islamic Economics, King Abdul Aziz University.

Siddiqi, M. N. (1985). Partnership and Profit Sharing in Islamic Law. Leicester: The Islamic Foundation. Winstedt, R. (1969). A History of Classical Malay Literature. Oxford: Oxford University Press.

Yakcop, N. M. (1996). Teori, amalan and prospek sistem kewangan Islam di Malaysia. Kuala Lumpur: Utusan Publications \& Distributors.

Yasin, N.M. (1996). Islamization/Malaynizaton: A Study of the Role of Islamic Law in the Economic Development of Malaysia: 1969-1993. Kuala Lumpur: Dewan Bahasa dan Pustaka.

Zaim, I. M., Rosland, A., Taqiuddin, M. (2015). Perbankan Islam Di Malaysia: Tinjauan Strategi Pengukuhannya. Labuan e-Journal of Muamalat and Society, 9, 48-56. 